\title{
Incidence of colorectal cancer in BRCA1 and BRCA2 mutation carriers: results from a follow-up study
}

C M Phelan ${ }^{1}$, J lqbal ${ }^{2}, \mathrm{H}$ T Lynch ${ }^{3}$, J Lubinski ${ }^{4}, \mathrm{~J} \mathrm{Gronwald}^{4}, \mathrm{P} \mathrm{Moller}^{5}$, P Ghadirian ${ }^{6}$, W D Foulkes ${ }^{7}, \mathrm{~S} \mathrm{Armel}^{8}$, A Eisen ${ }^{9}, \mathrm{~S}$ L Neuhausen ${ }^{10}$, L Senter ${ }^{11}$, C F Singer ${ }^{12}$, P Ainsworth ${ }^{13}$, C Kim-Sing ${ }^{14}$, N Tung ${ }^{15}$, M Llacuachaqui ${ }^{2}$, G Chornokur ${ }^{1}$, S Ping ${ }^{2}$, S A Narod ${ }^{\star 2}$ and the Hereditary Breast Cancer Study Group

${ }^{1}$ Department of Cancer Epidemiology, Moffitt Cancer Center, 12902 Magnolia Drive, Tampa, FL 33647, USA; ${ }^{2}$ Familial Breast Cancer Research, Women's College Research Institute, 790 Bay Street, Toronto, Ontario M5G 1N8, Canada; ${ }^{3}$ Department of Preventive Medicine and Public Health, Creighton University School of Medicine, 2500 California Plaza, Omaha, NE 68178, USA; ${ }^{4}$ International Hereditary Cancer Center, Pomeranian Medical University, Al. Powstancow Wlpk. 72, 70-111 Szczecin, Poland; ${ }^{5}$ Norwegian Radium Hospital N-0310, Oslo, Norway; ${ }^{6}$ Epidemiology Research Unit, Research Centre of the University of Montreal Hospital Centre (CRCHUM), 3850 Street, Urbain, Montreal, Quebec H2W 1T8, Canada; ${ }^{7}$ Program in Cancer Genetics, Department of Oncology, McGill University, 1650 Cedar Avenue, Montreal, Quebec H3G 1A4, Canada; ${ }^{8}$ Department of Obstetrics and Gynecology, University of Toronto and Gynecologic Oncology, Princess Margaret Hospital, Toronto, Ontario M5G 2M9, Canada; ${ }^{9}$ Sunnybrook Regional Cancer Centre, Toronto, Ontario M4N 3M5, Canada; ${ }^{10}$ Department of Population Sciences, Beckmann Research Institute, City of Hope, Duarte, CA 91010, USA; ${ }^{11}$ Division of Human Genetics, The Ohio State University Medical Center, Comprehensive Cancer Center, Columbus, OH 43210, USA; ${ }^{12}$ Department of Obstetrics and Gynecology and Comprehensive Cancer Center, Medical University of Vienna, Spitalgasse 23, 1090, Vienna, Austria; ${ }^{13}$ London Regional Cancer Program, London, Ontario N6A 4L6, Canada; ${ }^{14}$ BC Cancer Agency, 675 West 10th Avenue, Vancouver, BC V5Z 1L3, Canada and ${ }^{15}$ Beth Israel Deaconess Medical Center, Cancer Risk and Prevention Program, 330 Brookline Avenue, Boston, MA 02215, USA

Background: The BRCA1 and BRCA2 genes confer increased susceptibility to breast and ovarian cancer and to a spectrum of other cancers. There is controversy regarding the risk of colorectal cancer conferred by germline mutations in these two genes.

Methods: We followed 7015 women with a BRCA mutation for new cases of colorectal cancer. Incidence rates in carriers were compared with population-specific incidence rates, and standardised incidence ratios (SIRs) were estimated. The expected numbers of cancers were computed by multiplying person-years at risk by the appropriate age-, sex- and country-specific incidence rates from the five countries.

Results: Twenty-one incident colorectal cancer cases were observed among all mutation carriers, compared with 23.6 cases expected. The SIR for BRCA1 carriers was 0.92 (95\% confidence interval $(\mathrm{Cl}), 0.54-1.40, P=0.7$ ) and for BRCA2 carriers was 0.82 (95\% Cl, 0.30-1.81, $P=0.7$ ). The SIR for colon cancer was 3.81 (95\% Cl 1.77-7.23) for women below the age of 50 years (both genes combined) and was 0.60 (95\% $\mathrm{Cl} 0.33-1.00)$ for women aged 50 years and above.

Conclusion: The risk of colorectal cancer is increased in female carriers of BRCA1 mutations below the age of 50 years but not in women with BRCA2 mutations or in older women.

${ }^{\star}$ Correspondence: Dr SA Narod; E-mail: steven.narod@wchospital.ca

Received 31 May 2013; revised 22 October 2013; accepted 25 October 2013; published online 28 November 2013

(c) 2014 Cancer Research UK. All rights reserved 0007-0920/14 
The BRCA1 and BRCA2 genes confer increased susceptibility to breast and ovarian cancers (Wooster et al, 1995; Ford et al, 1998; Satagopan et al, 2001; Thompson et al, 2001; Antoniou et al, 2003) and to a spectrum of other cancers (Struewing et al, 1997; Breast Cancer Linkage Consortium, 1999; Brose et al, 2002; Thompson and Easton, 2002; King et al, 2003). However, the risk for colorectal cancers associated with $B R C A 1$ and $B R C A 2$ mutations remains unclear. Previous studies that were designed to estimate the risk of colon cancer among mutation carriers were based on crosssectional reviews of family histories of women with mutations and were susceptible to both selection bias and misclassification. The diagnoses of colorectal cancer were based on information provided by a family member and this approach may not always be accurate. Further, in previous studies, the mutation status of the colorectal cancer cases was unknown. We conducted a prospective study of the incidence of colorectal cancer in a cohort of $B R C A 1$ and $B R C A 2$ mutation carriers. We followed 7105 women with a BRCA1 or a $B R C A 2$ mutation for a mean of 5.5 years. The knowledge of colorectal cancer incidence rates has important implications for genetic counsellors and their patients and for developing appropriate screening policies.

\section{MATERIALS AND METHODS}

Study population. Eligible study participants were women at one of 50 centres in five countries from Canada, the United States or Europe who carry a deleterious BRCA1 or BRCA2 mutation. In most cases, genetic testing was offered initially to women who were affected either by breast or ovarian cancer. When a mutation in either $B R C A 1$ or $B R C A 2$ was found in a proband or in her relative, testing was offered to other at-risk women in her family, both affected and unaffected. In some cases, mutation testing was offered directly to unaffected women when no affected family member was available for testing. The criteria for genetic testing varied from centre to centre; however, all participating facilities offered testing to both affected and unaffected women. Mutation detection was performed using a range of techniques; however, all abnormal nucleotide sequences were confirmed using direct Sanger sequencing. A woman was eligible for the study when the molecular analysis established that she was a mutation carrier. She was then asked to participate in this prospective study and to complete a baseline questionnaire. Participants were enrolled in the study from 1992 to 2010. The majority of participants completed the baseline questionnaire at the time of genetic testing or within 1 year of receiving their result. This is a dynamic cohort with ongoing accrual and, therefore, the lengths of follow-up varied from individual to individual. Participants completed a baseline questionnaire and at least one follow-up questionnaire, a minimum of 2 years following the baseline questionnaire. The baseline and follow-up questionnaires requested information regarding reproductive history, surgical history (including preventive oophorectomy and mastectomy) and all new diagnoses of cancers. All participants provided written informed consent for genetic testing and for participating in the prospective study. The ethics committees of all participating centres have approved the study.

The 7021 carriers were from 3878 different families. Of the 7021 women, six had data missing on key variables (for example, date of birth, date of questionnaires, gene mutation) and were excluded, leaving 7015 women in the final analysis. An attempt was made to retrieve the pathology report for each of the incident cases of colorectal cancer. We did not have data to determine whether the diagnosis was made through clinical symptoms or screening.

Statistical analysis. Women who had a history of breast cancer were eligible for follow-up but those with a history of ovarian cancer were considered ineligible. Women were followed from the date at the baseline until the date of last questionnaire, the diagnosis of colorectal cancer, diagnosis of ovarian cancer or death from another cause.

The risk of colorectal cancer in the BRCA1 and BRCA2 mutation carriers, relative to the general population, was estimated with standardised incidence ratios (SIRs). The SIR was obtained by calculating the ratio of observed to expected number of new colorectal cancer cases, for all women combined and then separately for BRCA1 and the BRCA2 carriers. The observed and expected numbers of colorectal cancers were derived separately for carriers from each of five countries (Canada, United States, Poland, France and Norway). First, the annual age-standardised incidence rates of colorectal cancer were calculated with the count (numerator) and person-year at risk (denominator). The person-years at risk were calculated using the total number of $B R C A 1$ and BRCA2 carriers multiplied with the average follow-up time in years. The person-years were subcategorised according to different countries and different age groups. The age-standardised incidence rates for each participating country were obtained from GLOBOCAN 2008 (Ferlay et al, 2010). The major source of incidence rates estimated by GLOBOCAN 2008 is the Cancer Incidence in Five Continents published by the International Agency for Research on Cancer (IARC) (Parkin et al, 2002; Curado et al, 2007). In GLOBOCAN 2008, these data are incorporated with the most recent available data from populationbased cancer registries until 2002. The expected number of colorectal cancers was calculated by multiplying each agestandardised incidence rate of the country-specific general population by the observed person-years in our BRCA cohort and divided by 100000 to get the expected numbers of colorectal cancers (indirect standardisation method). $P$-values were calculated under the assumption that the observed cancers are random variables with a Poisson distribution. Confidence intervals were calculated with the exact tests and all $P$-values were two-tailed. The SIRs were also estimated for age subgroups $<50$ years and $\geqslant 50$ years.

Colorectal cancer coding. GLOBOCAN 2008 has used International Classification of Disease (ICD, 10th revision) coding system to classify the cancers according to the site of origin (Suchy et al, 2010). In the ICD, 10th revision, colorectal cancers are listed as 'Colorectum (C18-21)' with the individual cancer sites coded as: C18.0-Cecum, C18.1-Appendix, C18.2-Ascending colon, C18.3Hepatic flexure of colon, C18.4-Transverse colon, C18.5-Splenic flexure of colon, C18.6-Descending colon, C18.7-Sigmoid colon, C18.8-Overlapping lesion of colon, C18.9-Colon, NOS, C19.9Rectosigmoid junction, C20.9-Rectum, NOS, C21.0-Anus, NOS, C21.1-Anal canal, C21.2-Cloacogenic zone, and C21.8-Overlapping lesion of rectum, anus, and anal canal. The epidemiology and risk factors of anal cancers are different from the cancers of colon and rectum; however, GLOBOCAN does not differentiate between these subtypes when estimating incidence rates. Instead, it estimates the rates for the entire region of colorectum including colon, rectum and anal canal.

\section{RESULTS}

The 7015 women in our database of $B R C A 1$ and $B R C A 2$ carriers were followed for a mean of 5.5 years. The mean age of the cohort at study entry was 47.3 years (range, 30-74 years). A total of 5481 participants $(78.13 \%)$ carried a BRCA1 mutation, $1474(21.01 \%)$ carried a $B R C A 2$ mutation, and 60 participants $(0.8 \%)$ carried both a BRCA1 and a BRCA2 mutation. A total of 2829 women (40\%) had a past history of breast cancer.

We identified 21 new colorectal cancer cases among the $B R C A 1$ and BRCA2 carriers vs 23.6 colorectal cancers expected 
$(\mathrm{SIR}=0.89, P=0.6)$. Of the 21 colorectal cancer cases, 16 cases occurred in BRCA1 carriers vs 17.4 colorectal cancers expected $(\mathrm{SIR}=0.92, P=0.7)$ and 5 cases occurred in BRCA2 carriers vs 6.1 colorectal cancers expected $(\mathrm{SIR}=0.82, P=0.7) \quad($ Table 1$)$. The characteristics of the 14 colorectal cases (including four cases of anal cancer) for whom a pathology report was retrieved are presented in Table 2.

The mean age of diagnosis for the cases of colorectal cancer was 56.3 years (53.5 years for the BRCA1 mutation carriers and 57.3 years for the $B R C A 2$ mutation carriers). For women above the age of 50 years, the annual incidence rate was 46 per 100000 per year for BRCA1 carriers and was 87 per 100000 per year for BRCA2 carriers (Table 3 ). For women below the age of 50 years, the annual incidence rate was 62 per 100000 per year for BRCA1 carriers and was 40 per 100000 per year for $B R C A 2$ carriers. In the subgroup analysis of BRCA1 carriers, for women aged 30-39 years, the annual incidence rate was 34.9 per 100000 per year and for women aged 40-49 years the annual rate was 84.2 per 100000 per year. The risk of colorectal cancer was approximately four times greater than expected for young women (aged 30-49 years) (SIR = 3.81; $95 \%$ confidence interval (CI) 1.77-7.23). The risk of early-onset colorectal cancer was significantly elevated only for BRCA1 carriers. There were eight colorectal cancers in BRCA1 carriers before the age of 50 years, the youngest occurred at the age of

Table 1. Observed and expected number of colorectal cancer in BRCA1 and BRCA carriers according to the contributing country

\begin{tabular}{|c|c|c|c|c|c|c|c|c|}
\hline Country & BRCA status & $\mathbf{N}$ & Person-years & $\begin{array}{c}\text { Rate per } \\
100000\end{array}$ & $\begin{array}{c}\text { Observed } \\
\text { cancers }\end{array}$ & $\begin{array}{c}\text { Expected } \\
\text { cancers }\end{array}$ & SIR $(95 \% \mathrm{Cl})$ & $\begin{array}{c}P \text {-value } \\
\text { (two-tailed) }\end{array}$ \\
\hline Canada & $\begin{array}{c}\text { All } \\
\text { BRCA1 } \\
\text { BRCA2 }\end{array}$ & $\begin{array}{r}1760 \\
1012 \\
725\end{array}$ & $\begin{array}{r}10494 \\
6172 \\
4222\end{array}$ & $\begin{array}{l}76.23 \\
97.21 \\
47.37\end{array}$ & $\begin{array}{l}8 \\
6 \\
2\end{array}$ & $\begin{array}{l}9.16 \\
5.13 \\
3.96\end{array}$ & $\begin{array}{l}0.87(0.40-1.6) \\
1.17(0.47-2.4) \\
0.50(0.08-1.6)\end{array}$ & $\begin{array}{l}0.7 \\
0.6 \\
0.3\end{array}$ \\
\hline USA & $\begin{array}{c}\text { All } \\
\text { BRCA1 } \\
\text { BRCA2 }\end{array}$ & $\begin{array}{r}1853 \\
1253 \\
577\end{array}$ & $\begin{array}{r}10071 \\
7027 \\
2934\end{array}$ & $\begin{array}{l}59.58 \\
56.92 \\
68.16\end{array}$ & $\begin{array}{l}6 \\
4 \\
2\end{array}$ & $\begin{array}{l}6.64 \\
4.47 \\
2.1\end{array}$ & $\begin{array}{l}0.90(0.36-1.8) \\
0.89(0.28-2.1) \\
0.95(0.16-3.1)\end{array}$ & $\begin{array}{l}0.8 \\
0.8 \\
1\end{array}$ \\
\hline Austria & $\begin{array}{c}\text { All } \\
\text { BRCA1 } \\
\text { BRCA2 }\end{array}$ & $\begin{array}{r}141 \\
107 \\
20\end{array}$ & $\begin{array}{l}704 \\
548 \\
118\end{array}$ & $\begin{array}{c}142.04 \\
- \\
847.45\end{array}$ & $\begin{array}{l}1 \\
0 \\
1\end{array}$ & $\begin{array}{l}0.26 \\
0.18 \\
0.07\end{array}$ & $\begin{array}{c}3.85(0.19-19) \\
- \\
14.29(0.71-70.4)\end{array}$ & $\begin{array}{c}0.2 \\
- \\
0.07\end{array}$ \\
\hline Poland & $\begin{array}{c}\text { All } \\
\text { BRCA1 } \\
\text { BRCA2 }\end{array}$ & $\begin{array}{r}2475 \\
2468 \\
7\end{array}$ & $\begin{array}{r}11718 \\
11596 \\
22\end{array}$ & $\begin{array}{c}34.13 \\
34.49 \\
-\end{array}$ & $\begin{array}{l}4 \\
4 \\
0\end{array}$ & $\begin{array}{l}4.28 \\
4.23 \\
0.01\end{array}$ & $\begin{array}{c}0.93(0.29-2.2) \\
0.94(0.30-2.3) \\
-\end{array}$ & $\begin{array}{r}0.9 \\
0.9 \\
-\end{array}$ \\
\hline Norway & $\begin{array}{c}\text { All } \\
\text { BRCA1 } \\
\text { BRCA2 }\end{array}$ & $\begin{array}{l}682 \\
556 \\
126\end{array}$ & $\begin{array}{r}5160 \\
4392 \\
803\end{array}$ & $\begin{array}{c}38.76 \\
45.54 \\
-\end{array}$ & $\begin{array}{l}2 \\
2 \\
0\end{array}$ & $\begin{array}{l}4.53 \\
3.76 \\
0.81\end{array}$ & $\begin{array}{c}0.44(0.07-1.6) \\
0.53(0.09-1.7) \\
-\end{array}$ & $\begin{array}{r}0.2 \\
0.3 \\
-\end{array}$ \\
\hline All countries & $\begin{array}{c}\text { All } \\
\text { BRCA1 } \\
\text { BRCA2 }\end{array}$ & $\begin{array}{l}7015 \\
5481 \\
1474\end{array}$ & $\begin{array}{r}38646 \\
30191 \\
8208\end{array}$ & $\begin{array}{l}54.34 \\
53 \\
60.96\end{array}$ & $\begin{array}{r}21 \\
16 \\
5\end{array}$ & $\begin{array}{c}23.6 \\
17.37 \\
6.1\end{array}$ & $\begin{array}{l}0.89(0.56-1.3) \\
0.92(0.54-1.4) \\
0.82(0.30-1.8)\end{array}$ & $\begin{array}{l}0.6 \\
0.7 \\
0.7\end{array}$ \\
\hline
\end{tabular}

Table 2. Characteristics of the incident cases of colorectal cancer in BRCA mutation carriers

\begin{tabular}{|c|c|c|c|c|c|c|}
\hline Pedigree number & Age & BRCA status & Tumour site & Tumour pathology & Tumour grade & Duke's stage \\
\hline CR1973 & 46 & BRCA1 & Anal canal & Squamous cell carcinoma & Grade 2 & Unk \\
\hline UU2802 & 51 & BRCA1 & Colon & Adenocarcinoma & Unk & Unk \\
\hline BCW141 & 57 & BRCA1 & Right colon & Adenocarcinoma & Grade 2 & Duke B \\
\hline BC169 & 48 & BRCA1 & Right colon & Adenocarcinoma & Grade 3 & Duke C \\
\hline NR1575 & 32 & BRCA1 & Left colon & Adenocarcinoma & Grade 2 & Duke C \\
\hline NR1353 & 55 & BRCA1 & Transverse colon & Adenocarcinoma & Grade 3 & Duke C \\
\hline PD121177 & 61 & BRCA1 & Unknown & Adenocarcinoma & Grade 2 & Unk \\
\hline PD56009 & 44 & BRCA1 & Anal canal & Squamous cell carcinoma & Unk & Unk \\
\hline ED37623 & 65 & BRCA1 & Rectum & Adenocarcinoma & Grade 1 & Duke C \\
\hline HM1030 & 56 & BRCA1 & Anal canal & Squamous cell carcinoma & Grade 3 & Unk \\
\hline AUF089 & 62 & BRCA2 & Sigmoid colon & Adenocarcinoma & Grade 2 & Duke B \\
\hline SB42233 & 65 & BRCA2 & Transverse colon & Adenocarcinoma & Grade 2 & Duke B \\
\hline CLC018 & 77 & BRCA2 & Sigmoid colon & Adenocarcinoma & Grade 2 & Duke A \\
\hline VT9729 & 55 & BRCA2 & Anal canal & Squamous cell carcinoma & Grade 1 & Unk \\
\hline
\end{tabular}




\begin{tabular}{|c|c|c|c|c|c|c|c|c|}
\hline BRCA status & Age (years) & $\mathbf{N}$ & Person-years & $\begin{array}{c}\text { Rate per } \\
100000\end{array}$ & $\begin{array}{c}\text { Observed } \\
\text { cancers }\end{array}$ & $\begin{array}{c}\text { Expected } \\
\text { cancers }\end{array}$ & $\operatorname{SIR}(95 \% \mathrm{CI})$ & $\begin{array}{c}P \text {-value } \\
\text { (two-tailed) }\end{array}$ \\
\hline All & $\begin{array}{l}30-49 \\
50-74\end{array}$ & $\begin{array}{l}3194 \\
3821\end{array}$ & $\begin{array}{l}15466 \\
23180\end{array}$ & $\begin{array}{l}51.73 \\
56.08\end{array}$ & $\begin{array}{r}8 \\
13\end{array}$ & $\begin{array}{r}2.10 \\
21.50\end{array}$ & $\begin{array}{l}3.81(1.77-7.2) \\
0.60(0.33-1)\end{array}$ & $\begin{array}{l}0.001 \\
0.05\end{array}$ \\
\hline BRCA1 & $\begin{array}{l}30-49 \\
50-74\end{array}$ & $\begin{array}{l}2638 \\
2843\end{array}$ & $\begin{array}{l}12848 \\
17342\end{array}$ & $\begin{array}{l}62.27 \\
46.13\end{array}$ & $\begin{array}{l}8 \\
8\end{array}$ & $\begin{array}{r}1.68 \\
15.68\end{array}$ & $\begin{array}{l}4.76(2.21-9) \\
0.57(0.28-1)\end{array}$ & $\begin{array}{c}<0.001 \\
0.07\end{array}$ \\
\hline BRCA2 & $\begin{array}{l}30-49 \\
50-74\end{array}$ & $\begin{array}{l}554 \\
980\end{array}$ & $\begin{array}{l}2486 \\
5722\end{array}$ & $\begin{array}{c}- \\
87.38\end{array}$ & $\begin{array}{l}0 \\
5\end{array}$ & $\begin{array}{l}0.39 \\
5.70\end{array}$ & $\begin{array}{c}-- \\
0.87(0.32-1.9)\end{array}$ & $\overline{0.8}$ \\
\hline
\end{tabular}

32 years and the others at ages 38,41, 43, 46, 47, 48, and 49 years. There was no evidence of an increase in the risk of colorectal cancer for women aged above 50 years (13 cancers observed, 21.5 cancers expected).

In addition to the 21 new cases of colorectal cancer, there were single cases of cancer of the gall bladder and bile duct. Owing to the small numbers of these cases, SIRs were not estimated. No case of stomach cancers was reported in the follow-up period.

\section{DISCUSSION}

We have estimated the risks for cancer of the colorectum, gall bladder, bile duct, and stomach among women with a $B R C A 1$ or a $B R C A 2$ mutation. There were only single cases of cancers of the gall bladder and bile duct (and no case of stomach cancer), and therefore it was not possible to do a formal analysis for these. In contrast, there were 21 cases of colorectal cancer; however, the incidence was not in excess of what we would have expected by chance, based on population rates for the five countries. However, the risk of early-onset colorectal cancer was significantly increased for young BRCA1 carriers.

Our findings are consistent with the studies of cancers represented in the Breast Cancer Linkage Consortium (Thompson et al, 2001), wherein the authors reported modest but significant increases in colorectal cancer risk in family members of families with a $B R C A 1$ or a $B R C A 2$ mutation. The relative risk associated with a $B R C A 1$ mutation was 2.03 $(\mathrm{RR}=2.03,95 \%$ CI $1.45-2.85, P<0.001)$ (Ford et al, 1998). Easton and Thompson (2001) performed a comprehensive assessment of the cancer risks to BRCA2 mutation carriers in these families. Significantly increased risks in carriers were observed for cancers of the stomach $(\mathrm{RR}=2.59 ; 95 \%$ CI $41.46-4.61$; $P=0.012)$ and gall bladder and bile ducts $(\mathrm{RR}=4.97 ; 95 \%$ CI 41.50-16.52; $P=0.03)$ but not for colon cancer $(\mathrm{RR}=1.43$; 95\% CI $0.79-2.58)$ or rectal cancer $(\mathrm{RR}=1.11 ; 95 \%$ CI $0.48-2.60)$ (Niell et al, 2004).

In a recent study, 2398 unselected patients with colorectal cancer and 4570 controls from Poland were screened for three BRCA1 founder mutations (Suchy et al, 2010). A BRCA1 mutation was present in $0.42 \%$ of unselected cases of colorectal cancer and in $0.48 \%$ of controls $(\mathrm{OR}=0.8 ; P=0.8)$. In keeping with our findings, BRCA1 mutations were more common than this $(0.82 \%)$ in 851 cases who were diagnosed with colorectal cancer at the age of 60 years or earlier $(\mathrm{OR}=1.7)$; however, this was not significant $(P=0.3)$. In a similar study conducted in Ashkenazi Jews, Niell et al (2004) identified a founder mutation in BRCA1 or BRCA2 in 24 of 1422 colon cancer cases and in 20 of 1566 controls $(\mathrm{OR}=1.24,95 \% \mathrm{CI}=0.68-2.26)$.

In a population-based series of 649 unselected incident cases of ovarian cancer, Risch et al (2001) identified 60 mutations among 515 women with invasive ovarian cancers, 39 in BRCA1 and 21 in
BRCA2. The risk of colorectal cancer was increased three-fold for relatives of cases carrying a BRCA2 mutation. The risk of stomach cancer was increased six-fold among first-degree relatives of cases carrying a BRCA1 mutation, compared with relatives of noncarriers. We reported no incident case of stomach cancer in our cohort. Jakubowska et al (2003) observed a strong association between co-occurrence of ovarian cancer and stomach cancer in a family and the presence of a BRCA2 mutation in Poland. The increased risk of stomach cancer in BRCA2 carriers was observed predominantly in males. Bermejo et al (2004) conducted a large retrospective population study in Swedish families eligible for BRCA1/2 testing. A two-fold increased incidence of stomach cancer was observed; most individuals diagnosed with stomach cancer were men. The authors suggest an association of BRCA1 mutation carrier status in men with stomach cancer.

Our study provides the strongest evidence to date for an increased risk of colon cancer in young women with a BRCA1 or a BRCA2 mutation. The primary strength of our study is that this is a large-scale prospective study in women confirmed to carry a BRCA1 or a BRCA2 mutation. Many previous studies used a historical cohort design, whereby genetic testing took place after the diagnoses of the incident cancers. Historical cohort studies are subject to bias because women who experience the end point of interest (colon, rectal and stomach cancer) may be more (or less) likely to undergo testing than healthy women because of local genetic testing criteria or high mortality. Our study has a number of limitations pertaining to both the estimation of the incidence and overall survival. Our cohort study includes only women and, therefore, we cannot estimate the incidence of colorectal cancer in males. The number of incident cases was relatively small $(n=21)$ and this limits the precision of the risk estimates, especially for subgroup analyses. We were able to retrieve a pathology report or a medical record on 14 of the cases $(66.6 \%)$ and the remainder $(n=7)$ were based on personal reporting. It is possible therefore that some of these seven were misclassified.

We observed four cases of anal cancer in this study, three in BRCA1 carriers and one in a BRCA2 carrier. Anal cancer is a very rare malignancy in the United States with an incidence rate of 1.7 per 100000 (Howlader et al, 2012). Based on the US rates, we expected to see 1.3 cases of anal cancer in the study (SIR 3.03, $P=0.05$ ).

The US Preventive Services Task Force (USPSTF) recommends general population screening for colorectal cancer using highsensitivity fecal occult blood testing, sigmoidoscopy, or colonoscopy beginning at the age of 50 years and continuing until the age of 75 years (U.S. Preventive Services Task Force, 2008). However, they recommend that people at higher risk of developing colorectal cancer should begin screening at a younger age and may need to be tested more frequently. Based on the results reported here, we recommend screening for colorectal cancer for women with a BRCA1 mutation be initiated at an age of 40 years. There are insufficient data to make a recommendation for BRCA2 carriers that is different from those of the general population. 


\section{ACKNOWLEDGEMENTS}

We thank the Canadian Cancer Society Research Institute for their ongoing support. SN is supported by a Canada Research Chair. We would like to thank Linda Steele for study enrolment and data collection. SLN is the Morris and Horowitz Families Endowed Professor and this work was supported by NIH R01 CA74415.

\section{REFERENCES}

Antoniou A, Pharoah PD, Narod S, Risch HA, Eyfjord JE, Hopper JL, Loman N, Olsson H, Johannsson O, Borg A, Pasini B, Radice P, Manoukian S, Eccles DM, Tang N, Olah E, Anton-Culver H, Warner E, Lubinski J, Gronwald J, Gorski B, Tulinius H, Thorlacius S, Eerola H, Nevanlinna H, Syrjakoski K, Kallioniemi OP, Thompson D, Evans C, Peto J, Lalloo F, Evans DG, Easton DF (2003) Average risks of breast and ovarian cancer associated with BRCA1 or BRCA2 mutations detected in case Series unselected for family history: a combined analysis of 22 studies. Am J Hum Genet 72: 1117-1130.

Bermejo JL, Pérez AG, Hemminki K (2004) Contribution of the Defective BRCA1, BRCA2 and CHEK2 genes to the familial aggregation of breast cancer: a simulation study based on the Swedish Family-Cancer Database. Hered Cancer Clin Prac 2: 185-191.

Breast Cancer Linkage Consortium (1999) Cancer risks in BRCA2 mutation carriers. J Natl Cancer Inst 91: 1310-1316.

Brose MS, Rebbeck TR, Calzone KA, Stopfer JE, Nathanson KL, Weber BL (2002) Cancer Risk estimates for BRCA1 mutation carriers identified in a risk evaluation program. J Natl Cancer Inst 94: $1365-1372$

Curado MP, Edwards B, Shin HR, Storm H, Ferlay J, Heanue M, Boyle P (eds) (2007) Cancer Incidence in Five Continents Vol. IXIARC Scientific Publications No. 160: Lyon, IARC.

Ferlay J, Shin HR, Bray F, Forman D, Mathers C, Parkin DM (2010) GLOBOCAN 2008 v2.0, Cancer Incidence and Mortality Worldwide: IARC CancerBase No. 10 (Internet). Lyon, France: International Agency for Research on Cancer; Available from http://globocan.iarc.fr.

Ford D, Easton DF, Stratton M, Narod S, Goldgar D, Devilee P, Bishop DT, Weber B, Lenoir G, Chang-Claude J, Sobol H, Teare MD, Struewing J, Arason A, Scherneck S, Peto J, Rebbeck TR, Tonin P, Neuhausen S, Barkardottir R, Eyfjord J, Lynch H, Ponder BA, Gayther SA, Zelada-Hedman M. The Breast Cancer Linkage Consortium (1998) Genetic heterogeneity and penetrance analysis of the BRCA1 and BRCA2 genes in breast cancer families. The Breast Cancer Linkage Consortium. Am J Hum Genet 62: 676-689.

Howlader N, Noone AM, Krapcho M, Garshell J, Neyman N, Altekruse SF, Kosary CL, Yu M, Ruhl J, Tatalovich Z, Cho H, Mariotto A, Lewis DR, Chen HS, Feuer EJ, Cronin KA (eds) (2012) SEER Cancer Statistics Review, 1975-2010. National Cancer Institute: Bethesda, MD, USA

OTHER MEMBERS OF THE HEREDITARY BREAST CANCER CLINICAL STUDY GROUP:

Ophira Ginsburg, Lovise Maehle, Kevin Sweet, Dawna Gilchrist, Olufunmilayo I. Olopade, Fergus Couch, Claudine Isaacs, Beth Karlan, Charis Eng, Jeffrey N Weitzel, Mary B Daly, Judy E Garber, Dana Zakalik, Carey A Cullinane, Dominique Stoppa-Lyonnet, http://seer.cancer.gov/csr/1975_2010/ (based on November 2012 SEER data submission, posted to the SEER web site, 2013).

Jakubowska A, Scott R, Menkiszak J, Gronwald J, Byrski T, Huzarski T, Górski B, Cybulski C, Debniak T, Kowalska E, Starzyńska T, Ławniczak M, Narod S, Lubinski J (2003) A high frequency of BRCA2 gene mutations in Polish families with ovarian and stomach cancer. Eur J Hum Genet 11: 955-958.

King MC, Marks JH, Mandell JB. New York Breast Cancer Study Group (2003) Breast and ovarian cancer risks due to inherited mutations in BRCA1 and BRCA2. Science 302: 643-646.

Niell BL, Rennert G, Bonner JD, Almog R, Tomsho LP, Gruber SB (2004) BRCA1 and BRCA2 founder mutations and the risk of colorectal cancer. J Natl Cancer Inst 96: 15-21.

Parkin DM, Whelan SL, Ferlay J, Teppo L, Thomas DB (eds) (2002) Cancer Incidence in Five Continents Vol. VIIIIARC Scientific Publications No. 155: Lyon, IARC.

Risch HA, McLaughlin JR, Cole DE, Rosen B, Bradley L, Kwan E, Jack E, Vesprini DJ, Kuperstein G, Abrahamson JL, Fan I, Wong B, Narod SA (2001) Prevalence and penetrance of germline BRCA1 and BRCA2 mutations in a population series of 649 women with ovarian cancer. Am J Hum Genet 68: 700-710.

Satagopan JM, Offit K, Foulkes W, Robson ME, Wacholder S, Eng CM, Karp SE, Begg CB (2001) The lifetime risks of breast cancer in Ashkenazi Jewish carriers of BRCA1 and BRCA2 mutations. Cancer Epidemiol Biomarkers Prev 10: 467-473.

Struewing JP, Hartge P, Wacholder S, Baker SM, Berlin M, McAdams M, Timmerman MM, Brody LC, Tucker MA (1997) The risk of cancer associated with specific mutations of BRCA1 and BRCA2 among Ashkenazi Jews. N Engl J Med 336: 1401-1408.

Suchy J, Cybulski C, Górski B, Huzarski T, Byrski T, Dębniak T, Gronwald J, Jakubowska A, Wokołorczyk D, Kurzawski G, Kładny J, Jawień A, Banaszkiewicz Z, Wiśniowski R, Wandzel P, Starzewski J, Lorenc Z, Korobowicz E, Krokowicz P, Horbacka K, Lubiński J, Narod SA (2010) BRCA1 mutations and colorectal cancer in Poland Poland study. Fam Cancer 9: 541-544.

Thompson D, Easton D. Breast Cancer Linkage Consortium (2001) Variation in cancer risks, by mutation position, in BRCA2 mutation carriers. Am J Hum Genet 68: 410-419.

Thompson D, Easton DF (2002) Cancer incidence in BRCA1 mutation carriers. J Natl Cancer Inst 94: 1358-1365.

U.S. Preventive Services Task Force (2008) Screening for colorectal cancer: U.S. Preventive Services Task Force recommendation statement. Ann Intern Med 149: 627-637.

Wooster R, Bignell G, Lancaster J, Swift S, Seal S, Mangion J, Collins N, Gregory S, Gumbs C, Micklem G (1995) Identification of the breast cancer susceptibility gene BRCA2. Nature 378: 789-792.

This work is published under the standard license to publish agreement. After 12 months the work will become freely available and the license terms will switch to a Creative Commons AttributionNonCommercial-Share Alike 3.0 Unported License.

Howard Saal, Wendy Meschino, Wendy McKinnon, Marie Wood, Taya Fallen, Raluca Kurz, Siranoush Manoukian, Barry Rosen, Jeanna McCuaig, Rochelle Demsky, Edmond Lemire, Jane McLennan, Seema Panchal, Albert E Chudley, Susan T Vadaparampil, Tuya Pal, Daniel Rayson, Adriana Valentini, Susan Friedman (on behalf of FORCE) Cezary Cybulski, Tomasz Byrski, and Tomasz Huzarski 